${ }^{7}$ Funderbunk SJ, Crandall BF. Dominant piebald trait in a retarded child with a reciprocal translocation and small intercalary deletion. Am J Hum Genet 1974;26:715-22.

${ }^{8}$ Lacassie Y, Thurmon TF, Tracy MC, Pelias MZ. Piebald trait in a retarded child with interstitial deletion of chromosome 4. Am J Hum Genet 1977;29:641-2.

9 Lech H, Kubalska J, Wisniewski L. The child with congenital anomalies and interstitial deletion of the long arm of chromosome 4. Klin Padiatr 1982;194:117-9.

10 Campbell JM, Williams J, Batcup G. Interstitial deletion of chromosome 4q diagnosed prenatally. $J$ Med Genet 1986;23: 366-9.

11 Butler LJ, Palmer AV, Spencer T, Tabios-Broadway R, Wall WJ. A new interstitial deletion of chromosome no 4 del (4)(q22::q25). Clin Genet 1987;31:199-205.

12 Ligutic I, Brecevic L, Petkovic I, Kalogjera T, Rahic Z. Interstitial deletion of $4 \mathrm{q}$ and Rieger syndrome. Clin Genet 1981;20:323-7.
${ }^{13}$ Serville F, Broustet A. Pericentric inversion and partial monosomy $4 \mathrm{q}$ associated with congenital anomalies. Hum Genet 1977;39:239-42.

14 Motegi T, Nakamura K, Terakawa T, et al. Deletion of a single chromosome band 4q26 in a malformed girl: exclusion of Rieger syndrome associated gene(s) from the $4 \mathrm{q} 26$ segment. $J$ Med Genet 1988;25:628-33.

15 Valle Torrado MD, Labarta JD, Migliorini AM. Interstitial deletion of the long arm of chromosome 4 in a patient with mental retardation and abnormal phenotype. J Med Genet 1982;19:477-9.

${ }^{16}$ Hamill $M$, Sibert $J$, Hughes $H$. Interstitial deletion of $4 q$ in a mother and child. $J$ Med Genet 1988;25:279A.

Correspondence to Dr K Fagan, Cytogenetics Laboratory, Mater Hospital, Edith Street, Waratah, NSW 2298, Australia.

\title{
Cat eye syndrome associated with aganglionosis of the small and large intestine
}

\author{
JOHN WARD, IVÁN A SIERRA, AND ELIZABETH D'CROZ \\ Sección de Genética Clínica, Complejo Hospitalario Metropolitano de la Caja de Seguro Social, Panamá.
}

SUMmARY A newborn male infant is presented with the characteristic phenotype of the cat eye syndrome and a small supernumerary chromosome shorter than a 22 . He also had complete absence of parasympathetic ganglion cells throughout the small and large intestine.
The cat eye syndrome is characterised by anal atresia, ocular coloboma, cardiac defects, preauricular tags or sinuses, abnormalities of the urinary tract, mental retardation, and a small supernumerary, bisatellited, isodicentric chromosome. Molecular hybridisation with chromosome 22 specific probes have shown that the isodicentric chromosome

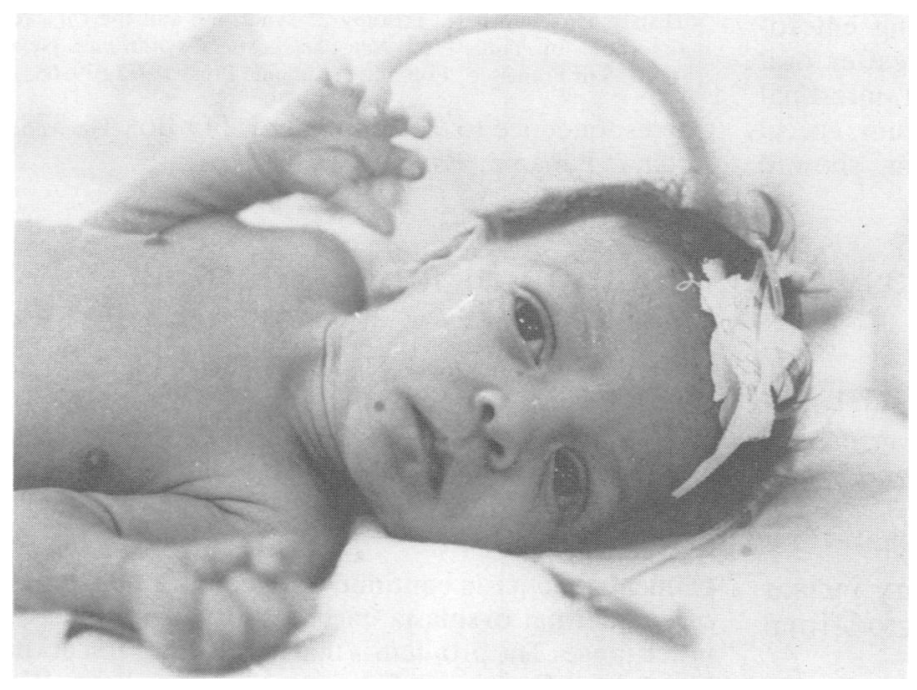

FIG 1 Coloboma of the iris and preauricular pits. 


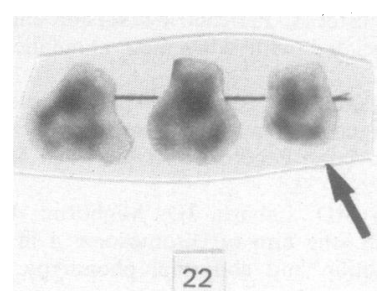

FIG 2 Partial karyotype of the patient with a supernumerary chromosome smaller than a $G$ chromosome.

carries three or four copies of D22S9 mapping at $22 \mathrm{q} 11 .{ }^{1}$

In this paper we report a male infant with the characteristic phenotype of the cat eye syndrome, who also had aganglionosis of the small and large intestine.

\section{Case report}

This was a newborn male infant born after 38 weeks' gestation by caesarean section. His Apgar score was 8 and 9 . He was the fourth child of a 31 year old mother and a 38 year old father. The three older sibs of the patient were normal and healthy.

Birth weight was $2620 \mathrm{~g}$, height $49 \mathrm{~cm}$, and head circumference $33 \mathrm{~cm}$. The following abnormalities were observed: coloboma of the iris (fig 1), bilateral preauricular pits, anal atresia, and bilateral cryptorchidism. Surgery was carried out during the first 24 hours after birth to resolve the anal atresia. The following day he developed a necrotising enterocolitis that was treated medically. Thereafter oral feeding became impossible because of intestinal obstruction. Biopsy of the duodenum, ileum, caecal appendix, sigmoid colon, and rectum showed absence of parasympathetic ganglion cells. The child died at three months of age; this was attributed to sepsis related to a central catheter for parenteral hyperalimentation.

\section{CYTOGENETIC STUDIES}

Cytogenetic studies on peripheral blood cells of the patient showed 47 chromosomes in all cells, with a supernumerary chromosome smaller than a G chromosome (fig 2). The karyotype of both parents was normal."

\section{Discussion}

Our diagnosis was made according to the minimal clinical criteria of Hsu and Hirschhorn, ${ }^{2}$ in that our patient had a combination of two major features, coloboma of the iris and anal atresia, plus one of the most frequent associated anomalies, preauricular pits. Also, the cytogenetic results in lymphocytes using $G$ banding showed a small supernumerary chromosome shorter than a 22 .

The outstanding feature in this case is the absence of parasympathetic ganglion cells throughout the intestinal tract. To our knowledge this is the first case of cat eye syndrome associated with a complete absence of ganglion cells in the large and small intestine. However, this association may be coincidental.

\footnotetext{
References

1 McDermid H, Duncan A, Brasch K, et al. Characterization of the supernumerary chromosome in cat eye syndrome. Science 1986;232:646-8.

${ }^{2}$ Hsu L, Hirschhorn K. Trisomy 22 syndrome and the cat eye syndrome. In: Yunis J, ed. New chromosomal syndromes. New York, San Francisco, London: Academic Press, 1977:339-68.
}

Correspondence to Dr John Ward, PO Box 10-378, Zona 4, Panamá, Panamá.

\title{
A single maxillary incisor as a manifestation of an ectodermal dysplasia
}

\author{
INGE BUNTINX* AND MICHAEL BARAITSER $†$ \\ ${ }^{*}$ Department of Medical Genetics, Universitaire Instelling Antwerpen, Universiteitsplein, 2610 Wilryk, \\ Belgium; and †Hospitals for Sick Children, Great Ormond Street, London WC1N 3JH.
}

SUMMARY A single, central, maxillary incisor was found in a patient with an ectodermal dysplasia.

Received for publication 17 January 1989.

Revised version accepted for publication 17 May 1989.
Clinical geneticists continue to encounter new types of ectodermal dysplasia each with its own mode of inheritance. The problem is that precise identification is essential for appropriate genetic counselling. We present two sibs with an abnormality of hair, nails, and teeth in which the dental anomaly in one of the 